
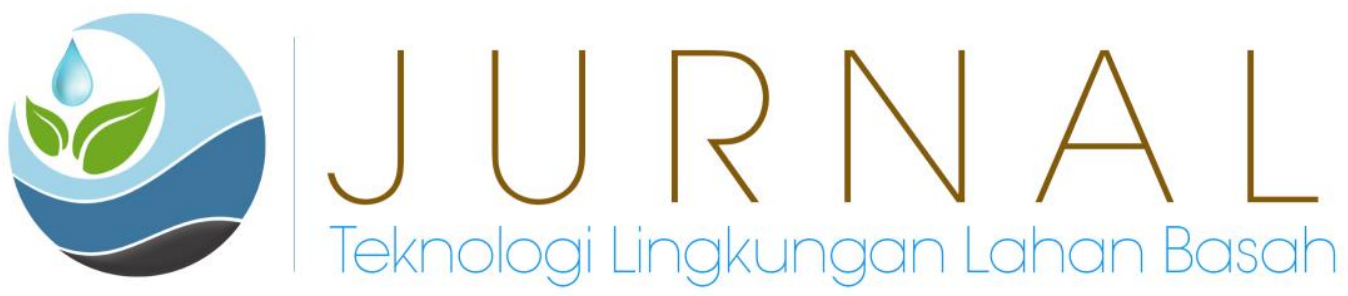

\title{
Analisis Bibliometrik dari Penelitian Bank Sampah untuk Pengelolaan Persampahan : 2008 - 2018 (Bibliometric Analysis of Waste Bank Research for Solid Waste Management: 2008 - 2018)
}

\author{
Laili Fitria $^{1}$, Ulli Kadaria ${ }^{2}$ \\ ${ }^{1}$ Kelompok Keahlian Teknologi dan Rekayasa Lingkungan Fakultas Teknik \\ Universitas Tanjungpura \\ ${ }^{2}$ Jurusan Teknik Lingkungan Fakultas Teknik Universitas Tanjungpura
}

E-mail : fitria.laili@gmail.com

\begin{abstract}
The concept of waste management through a waste bank was first researched in Thailand in 2008. It is known that waste banks can minimize the volume of waste that will be disposed of to landfill. Waste banks also create economic opportunities and can improve the quality of the environment. This research was conducted to find out how to manage waste through a waste bank. Scientific articles indexed by Dimensions (2008-2018) were analyzed by the systematic library review (SLR) method. The parameters analyzed include aspects of the number of articles published, journal choice, article writer, author's institution and country of origin, author collaboration, and the number of citations. The results of the analysis are visualized with the VOSviewer application. There are 99 scientific articles known and can be known by authors, institutions and any country in the world that study waste banks for waste management. Publications on waste banks tend to experience a significant increase from 2016 to 2018. Popular research topics are community-based waste management, changes in environmental care behavior, and performance evaluation and success factors for waste banks.
\end{abstract}

Keywords: bibliometric, systematic literature review, VOSviewer, waste bank.

\begin{abstract}
Abstrak
Konsep pengelolaan sampah melalui bank sampah pertama kali diteliti di Thailand pada tahun 2008. Diketahui bahwa bank sampah bisa meminimalkan volume limbah yang akan dibuang ke TPA. Bank sampah juga menciptakan peluang ekonomi dan bisa meningkatkan kualitas lingkungan. Penelitian ini dilakukan untuk mengetahui bagaimana pengelolaan sampah melalui bank sampah. Artikel ilmiah yang terindeks Dimensions (2008-2018) dianalisis dengan metode tinjauan pustaka sistematis (SLR). Parameter yang dianalisis meliputi aspek jumlah artikel yang terbit, pilihan jurnal, penulis artikel, institusi penulis serta asal negara, kolaborasi penulis, dan jumlah kutipan. Hasil analisa tersebut divisualisasikan dengan aplikasi VOSviewer. Diketahui ada 99 artikel ilmiah dan bisa diketahui penulis, institusi dan negara mana saja di dunia yang meneliti mengenai bank sampah dalam pengelolaan sampah. Publikasi mengenai bank sampah cenderung mengalami peningkatan yang signifikan dari tahun 2016 hingga 2018. Topik popular penelitian adalah manajemen pengelolaan sampah berbasis masyarakat, perubahan perilaku peduli lingkungan, serta evaluasi kinerja dan faktor keberhasilan bank sampah.
\end{abstract}

Kata kunci: bank sampah, bibliometrik, tinjauan pustaka sistematis, VOSviewer. 

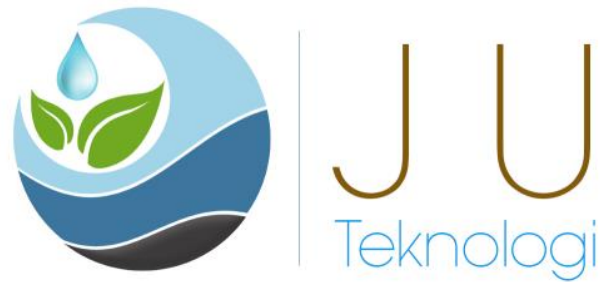
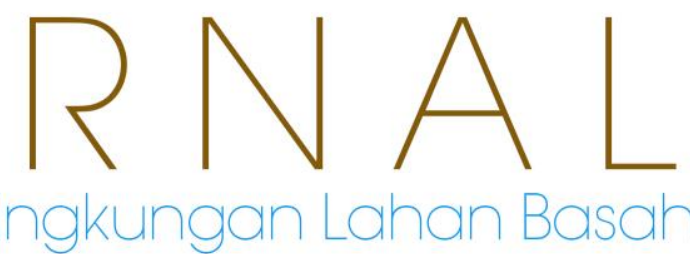

\section{PENDAHULUAN}

Adanya pertambahan penduduk dan perubahan pola konsumsi masyarakat menimbulkan bertambahnya volume, jenis dan karakteristik sampah. Selain itu, sampah telah menjadi permasalahan nasional, sehingga pengelolaannya perlu dilakukan secara komprehensif dan terpadu dari hulu ke hilir agar memberikan manfaat secara ekonomi, sehat bagi masyarakat, dan aman bagi lingkungan, serta dapat mengubah perilaku masyarakat. (Pemerintah Indonesia, 2008). Dalam UndangUndang Nomor 18 tahun 2008, pengelolaan sampah rumah tangga dan sampah sejenis rumah tangga dilakukan dengan 2 cara, yakni pengurangan sampah dan penanganan sampah. Dimana sampah rumah tangga maksudnya adalah sampah yang berasal dari kegiatan sehari-hari dalam rumah tangga, namun tidak termasuk tinja dan sampah spesifik. Sementara sampah sejenis rumah tangga yakni sampah yang berasal dari kawasan komersial, kawasan industri, kawasan khusus, fasilitas sosial, fasilitas umum dan fasilitas lainnya.

Sampai tahun 2015, ketentuan dalam UU-18/2008 telah diatur lebih jauh melalui PP-81/2012 mengenai Pengelolaan Sampah Rumah Tangga dan Sejenis Rumah Tangga (PRESIDEN REPUBLIK INDONESIA, 2012). Pengaturan yang lebih teknis terdapat pada Peraturan Menteri Pekerjaan Umum 03/PRT/M/2013 mengenai Penyelenggaraan Sarana dan Prasarana Sampah Rumah Tangga dan Sejenis Sampah Rumah Tangga (Damanhuri \& Padmi, 2016).

Selain itu, Pemerintah Indonesia melalui Peraturan Menteri Negara Lingkungan
Hidup Republik Indonesia Nomor 13 Tahun 2012 mengenai Pedoman Pelaksanaan Reduce, Reuse, Recycle melalui Bank Sampah. Peraturan ini menjadi pedoman bagi pelaksana kegiatan 3R melalui bank sampah (Menteri Negara Lingkungan Hidup Republik Indonesia, 2012).

Kegiatan reduce, reuse, dan recycle atau batasi sampah, guna ulang sampah dan daur ulang sampah yang selanjutnya disebut kegiatan 3R adalah segala aktivitas yang mampu mengurangi segala sesuatu yang dapat menimbulkan sampah, kegiatan penggunaan kembali sampah yang layak pakai untuk fungsi yang sama atau fungsi yang lain, dan kegiatan mengolah sampah untuk dijadikan produk baru. Bank sampah adalah tempat pemilahan dan pengumpulan sampah yang dapat didaur ulang dan/atau diguna ulang yang memiliki nilai ekonomi (Menteri Negara Lingkungan Hidup Republik Indonesia, 2012).

Bank sampah di Indonesia pertama kali didirikan di Yogyakarta pada tahun 2008. Pemerintah mengadopsi konsep Bank Sampah ini karena diyakini dapat digunakan untuk menurunkan jumlah sampah yang dibuang ke TPA. (Lestari, 2012). Penelitian ini dilakukan untuk mengetahui bagaimana Bank Sampah digunakan untuk pengelolaan persampahan berdasarkan tinjauan pustaka sistematis (SLR) dari 99 artikel ilmiah yang terindeks Dimensions yang terbit antara periode 2008 hingga 2018.

Menurut Fink (2005) dalam (Okoli \& Schabram, 2010) tinjauan pustaka sistematis (Systematic Literature Review 

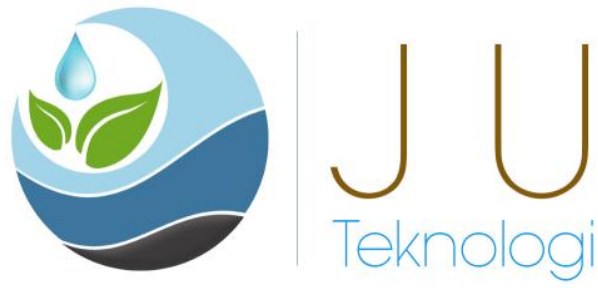

- SLR) merupakan sebuah ulasan yang sistematis, eksplisit, komprehensif dan merupakan metode yang dapat direproduksi untuk mengidentifikasi, mengevaluasi, dan mensintesis dari sebuah karya yang lengkap dan tulisan yang diproduksi oleh peneliti, cendekiawan, serta praktisi. Sebuah studi dari semua literatur yang tersedia harus terbuka (open minded) dan transparan tentang mengapa dan bagaimana topik dipilih, bagaimana fokusnya mungkin telah berubah selama pengembangan, atau dalam mendukung kebutuhan akan karya penulis selanjutnya, sebagaimana yang

\section{METODE PENELITIAN}

Dalam penelitian ini, metode tinjauan pustaka sistematis (SLR) terdiri dari dua langkah, yakni pemilihan artikel dan proceeding yang relevan dengan tema dan analisis artikel.

\section{Pemilihan Artikel dan Proceeding yang Relevan}

Data yang digunakan dalam penelitian ini merupakan kumpulan publikasi ilmiah mengenai bank sampah yang berasal dari pengindeks sedang Dimensions. Semua publikasi dan kutipan bersama dengan informasi kontekstual yang banyak - tersedia secara bebas untuk penggunaan pribadi, non-komersial. Akses menuju kumpulan data Dimensions cukup lengkap, komprehensif, dan terhubung pada data yang mencakup publikasi, hibah, paten, uji klinis, serta dokumen kebijakan.

Dimensions Analytics mendukung analisis data yang kompleks untuk memenuhi kebutuhan lembaga akademik, organisasi pemerintah, penyandang dana penelitian, penerbit,
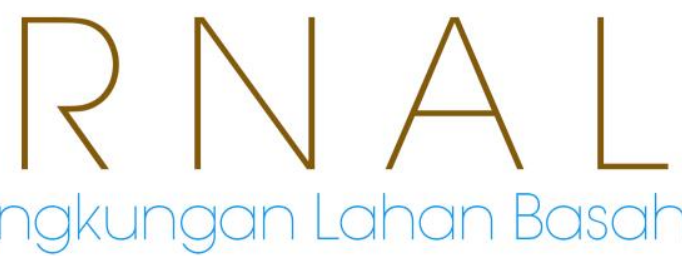

dituliskan oleh Hart, 1999 (Okoli \& Schabram, 2010). Seperti dituliskan oleh Thomas 2019, SLR sangat baik dilakukan sebelum memulai penelitian baru untuk mempelajari penelitian sebelumnya juga untuk mengetahui kecenderungan penelitian dunia dalam sebuah topik tertentu, bisa mengidentifikasi penelitian lain yang serupa dalam topik tersebut; dan untuk memastikan kebaruan dari sebuah potensi penelitian baru (Ulfa, Irawan, \& Kombaitan, 2019). Penelitian ini diharapkan mampu mengidentifikasi potensi kebaruan penelitian bank sampah di masa mendatang.

dan departemen Litbang. Dimensions merupakan portal interaktif yang dapat disesuaikan untuk menampilkan keahlian dan sumber daya di seluruh instansi.

Jenis publikasi yang digunakan dalam penelitian ini dibatasi pada artikel yang diterbitkan pada 2008 hingga 2018. Penelitian ini menggunakan kata kunci "waste bank" untuk pengambilan data. Langkah pertama seperti yang dirangkum pada Gambar 1, pada tahap pertama dilakukan pembatasan kriteria pencarian dengan kata kunci "waste bank". Terpilih 111 artikel yang terindeks pada Dimensions. Selanjutnya, dilakukan screening terhadap judul artikel yang membahas bank sampah terhadap limbah padat (sampah). Dari penelurusan dari judul, diketahui artikel bank sampah dimulai pada tahun 2008 yang ditulis oleh penulis dari Thailand. Sehingga penelitian ini dimulai dari 2008 hingga 2018. Selanjutnya terpilih 99 artikel yang akan dianalisis. 

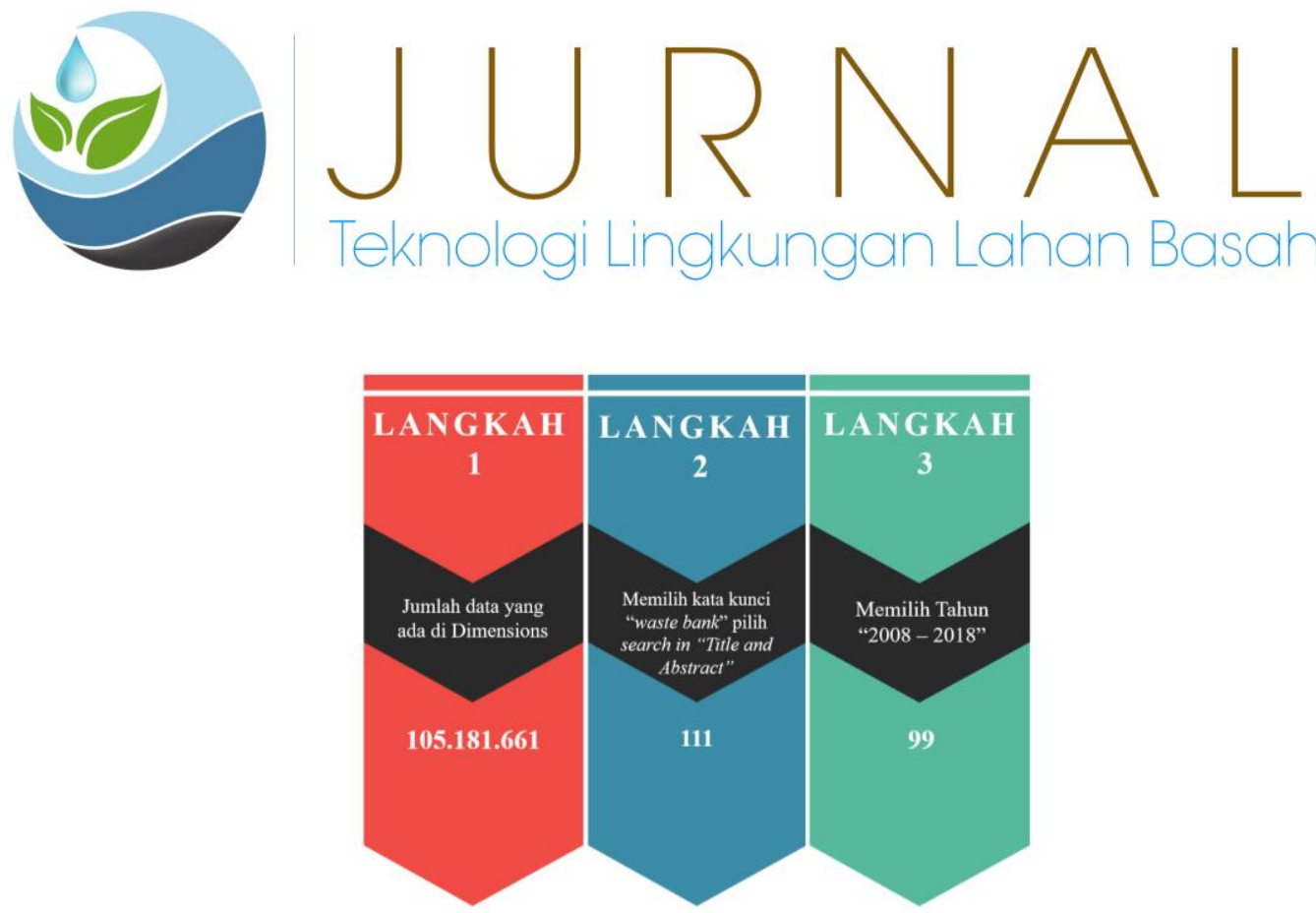

Gambar 1. Tahapan Penentuan Kriteria Pencarian Berbasis Data Dimensions

\section{Analisis Artikel}

\begin{tabular}{|c|c|}
\hline selanjutnya adalah & menghubungkan pengelompokan \\
\hline mengelompokkan 99 artikel terpilih & tersebut. VOSviewer adalah alat \\
\hline berdasarkan profil penulis, institusi & kat lunak untuk membuat \\
\hline $\begin{array}{llllllllll} & 1\end{array}$ & 年 \\
\hline dipilih untuk $\mathrm{m}$ & memvisualisasikan dan menjel \\
\hline $\begin{array}{l}\text { engenal waste bank mengg } \\
\text { erangkat lunak VOSviewer, jug }\end{array}$ & $\begin{array}{l}\text { peta-peta ini (van Eck \& Walt } \\
\text { 2017). }\end{array}$ \\
\hline
\end{tabular}

\section{HASIL DAN PEMBAHASAN}

Jumlah artikel yang diterbitkan setiap tahun

Hasil pencarian artikel mengenai bank sampah yang berhasil diidentifikasi berjumlah 99 artikel, dengan peningkatan pada 2 tahun terakhir. Pada 2016 dengan jumlah artikel sebanyak 15

artikel, menjadi 25 artikel pada 2017. Juga pada 2018 semakin meningkat menjadi 35 artikel. Hal ini menunjukkan bahwa penelitian bank sampah cenderung meningkat dari tahun ke tahun.

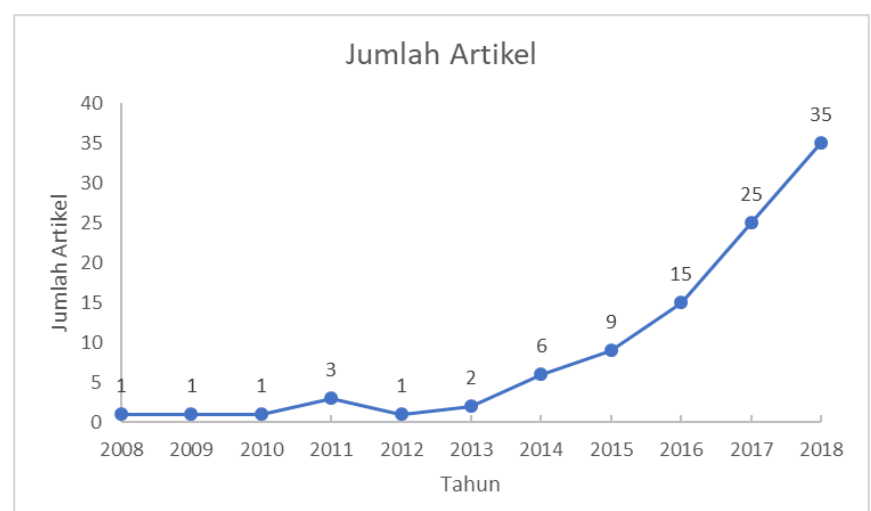

Gambar 2. Jumlah publikasi mengenai Bank Sampah dari tahun 2008 hingga 2018 

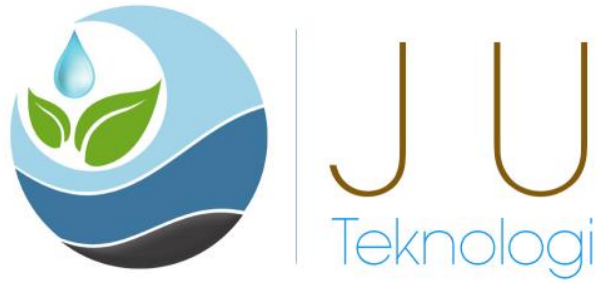

Untuk penerbit artikel, 99 artikel tersebut diterbitkan pada 65 jurnal yang berbeda dengan rentang tahun penerbitan dari 2008 hingga 2018. Tabel 1 merupakan daftar 15 jurnal atau prosiding yang paling banyak memuat artikel mengenai bank sampah, juga dilengkapi dengan
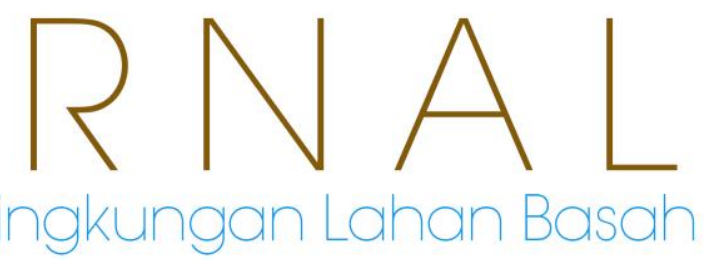

jumlah sitasi. Dari Tabel 1, diketahui bahwa Prosiding IOP Conference Series Earth and Environmental Science paling banyak dipilih untuk menerbitkan artikel mengenai bank sampah dari tahun 2008 hingga 2018, memuat 9 artikel mengenai bank sampah.

Tabel 1. Jurnal/Prosiding yang banyak dipilih untuk menerbitkan artikel bank sampah

\begin{tabular}{|c|l|c|c|}
\hline No & \multicolumn{1}{|c|}{ Jurnal/Prosiding } & $\begin{array}{c}\text { Jumlah } \\
\text { Artikel }\end{array}$ & $\begin{array}{c}\text { Jumlah } \\
\text { Sitasi }\end{array}$ \\
\hline 1 & $\begin{array}{l}\text { IOP Conference Series Earth and Environmental } \\
\text { Science }\end{array}$ & 9 & 0 \\
\hline 2 & Procedia - Social and Behavioral Sciences & 3 & 38 \\
\hline 3 & Sustainability & 3 & 16 \\
\hline 4 & International Journal of Waste Resources & 2 & 3 \\
\hline 5 & $\begin{array}{l}\text { Journal of Material Cycles and Waste } \\
\text { Management }\end{array}$ & 2 & 9 \\
\hline 6 & $\begin{array}{l}\text { IOP Conference Series Materials Science and } \\
\text { Engineering }\end{array}$ & 2 & 2 \\
\hline 7 & MATEC Web of Conferences & 2 & 3 \\
\hline 8 & $\begin{array}{l}\text { ECOTROPHIC Jurnal Ilmu Lingkungan (Journal } \\
\text { of Environmental Science) }\end{array}$ & 2 & 0 \\
\hline 9 & $\begin{array}{l}\text { Journal Sampurasun Interdisciplinary Studies for } \\
\text { Cultural Heritage }\end{array}$ & 2 & 0 \\
\hline 10 & ICCD & 1 & 0 \\
\hline 11 & Hygiene and Sanitation & 1 & 2 \\
\hline 12 & AIP Conference Proceedings & 1 & 33 \\
\hline 13 & Energy Procedia & & 1 \\
\hline 14 & Chemistry and Ecology & 2 & 3 \\
\hline 15 & Resources Conservation and Recycling & 2 & 2 \\
\hline
\end{tabular}



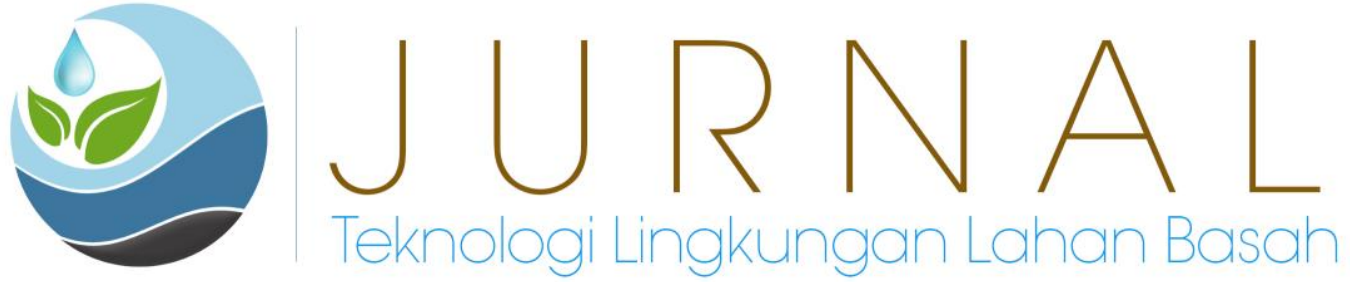

Tabel 2. Nama, institusi dan negara penulis artikel bank sampah yang diterbitkan

\begin{tabular}{|c|c|c|c|c|c|}
\hline No. & Nama Penulis & Institusi Penulis & Negara & $\begin{array}{l}\text { Jumlah } \\
\text { Artikel }\end{array}$ & $\begin{array}{c}\text { Jumlah } \\
\text { Sitasi }\end{array}$ \\
\hline 1 & Indriyani Rachman & $\begin{array}{l}\text { The University of } \\
\text { Kitakyushu }\end{array}$ & Japan & 4 & 11 \\
\hline 2 & $\begin{array}{l}\text { Helena Juliana } \\
\text { Kristina }\end{array}$ & $\begin{array}{l}\text { Pelita Harapan } \\
\text { University }\end{array}$ & Indonesia & 4 & 0 \\
\hline 3 & Christia Meidiana & $\begin{array}{l}\text { University of } \\
\text { Brawijaya }\end{array}$ & Indonesia & 3 & 5 \\
\hline 4 & Eric Jobiliong & $\begin{array}{l}\text { Pelita Harapan } \\
\text { University }\end{array}$ & Indonesia & 3 & 0 \\
\hline 5 & Toru Matsumoto & $\begin{array}{l}\text { The University of } \\
\text { Kitakyushu }\end{array}$ & Japan & 3 & 11 \\
\hline 6 & Slamet Raharjo & Andalas University & Indonesia & 3 & 11 \\
\hline 7 & 関戸 知雄 & - & - & 2 & 0 \\
\hline 8 & Chanathip Pharino & $\begin{array}{l}\text { Chulalongkorn } \\
\text { University }\end{array}$ & Thailand & 2 & 12 \\
\hline 9 & Agustina Christiani & $\begin{array}{l}\text { Pelita Harapan } \\
\text { University }\end{array}$ & Indonesia & 2 & 0 \\
\hline 10 & $\begin{array}{l}\text { Amornchai } \\
\text { Challcharoenwattana }\end{array}$ & $\begin{array}{l}\text { Chulalongkorn } \\
\text { University }\end{array}$ & Thailand & 2 & 12 \\
\hline 11 & $\begin{array}{l}\text { Muhamad Permana } \\
\text { Laksana }\end{array}$ & $\begin{array}{l}\text { Diponegoro } \\
\text { University }\end{array}$ & Indonesia & 2 & 1 \\
\hline 12 & $\begin{array}{l}\text { Noorhan Firdaus } \\
\text { Pambudi }\end{array}$ & $\begin{array}{l}\text { Institute of } \\
\text { technology } \\
\text { Bandung }\end{array}$ & Indonesia & 2 & 1 \\
\hline 13 & Akbar Adhiutama & $\begin{array}{l}\text { Institute of } \\
\text { technology } \\
\text { Bandung }\end{array}$ & Indonesia & 2 & 1 \\
\hline 14 & $\begin{array}{l}\text { Wichitra } \\
\text { Singhirunnusorn }\end{array}$ & $\begin{array}{l}\text { Mahasarakham } \\
\text { University }\end{array}$ & Thailand & 2 & 22 \\
\hline 15 & Anton Abdul Fatah & - & - & 2 & 0 \\
\hline
\end{tabular}

\section{Kontribusi Penulis}

Pada bagian ini akan membahas mengenai penulis, asal negara serta institusi penulis. Pada Tabel 2, bisa diketahui bahwa penulis yang memiliki artikel paling banyak mengenai bank sampah dari tahun 2008 hingga 2018, yakni Indriyani Rachman dari institusi The University of Kitakyushu dengan jumlah artikel sebanyak 4 artikel dan disitasi sebanyak 11 sitasi. Kemudian diikuti oleh Helena Juliana Kristina, Christia Meidiana, Eric Jobiliong, Toru Matsumoto yang memiliki 3 artikel. Dari Tabel 2 juga bisa dilihat bahwa negaranegara lain yang meneliti mengenai bank sampah antara lain, Jepang, Indonesia, Thailand. Berdasarkan data yang telah dikumpulkan, terdapat 244 penulis, namun tidak semua terhubung satu sama 

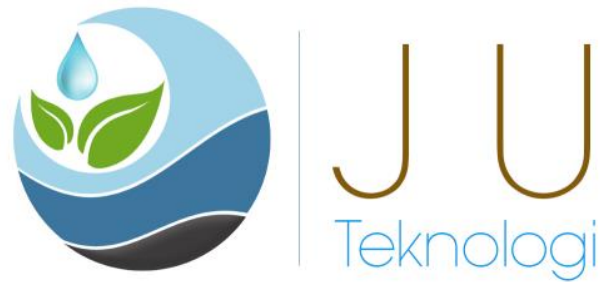

lain (berkolaborasi dalam penulisan artikel). Hubungan terbesar hanya terdiri dari 9 penulis yang divisualisasikan dengan aplikasi VOSviewer. Dari Gambar 3, dapat dilihat kolaborasi antar
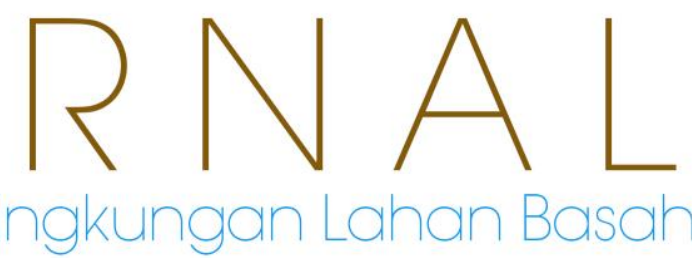

penulis artikel mengenai bank sampah. Juga bisa dilihat tahun penerbitan dari perbedaan warna pada penghubung antar penulis.

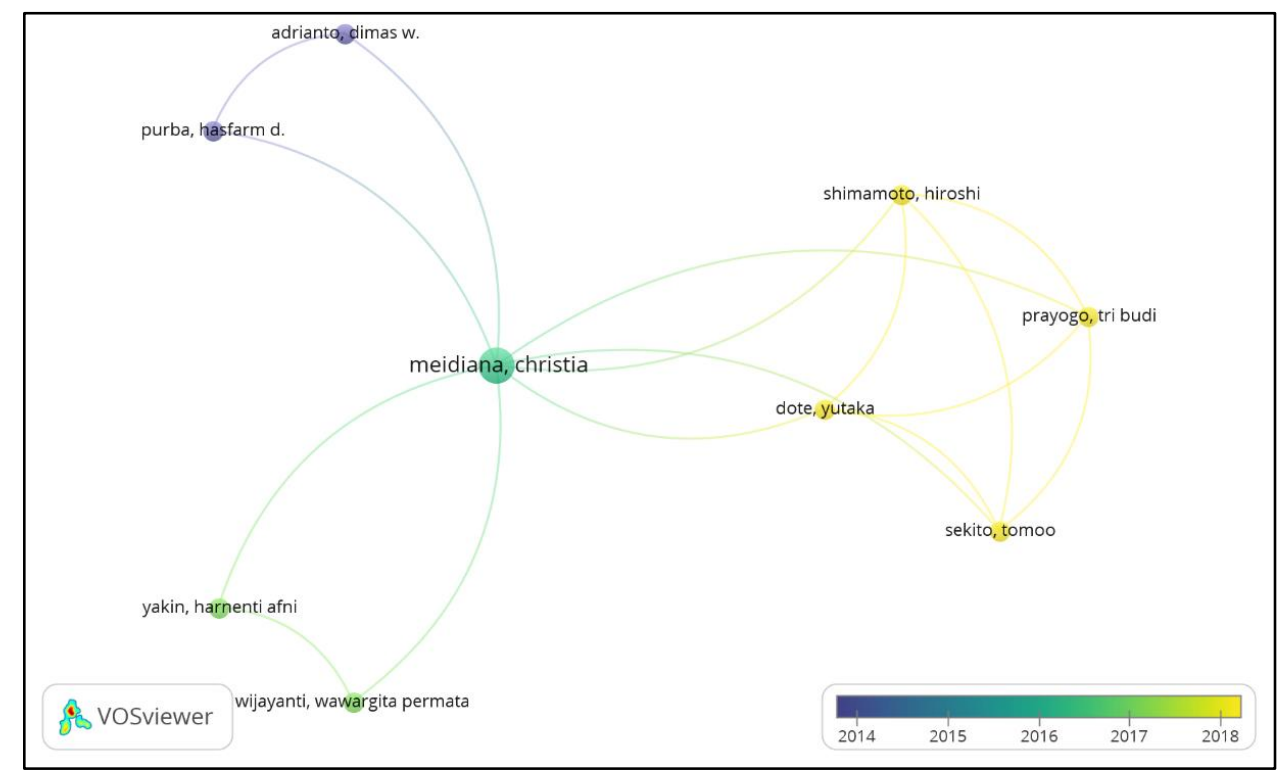

Gambar 3. Visualisasi dengan VOSviewer yang memperlihatkan cluster terbesar kolaborasi antar penulis dalam penelitian bank sampah

Dari tahun 2008 hingga 2018, diketahui ada 35 organisasi/institusi yang menulis mengenai bank sampah. Namun organisasi tersebut tidak semuanya terhubung satu sama lain. Namun ada 1 set/kluster terbesar yang menghubungkan 4 organisasi, yakni antara Leipzig University, University of Stuttgart, Fraunhofer Institute for Building Physics, dan University of Graz, (Wang, Maier, Horn, Holländer, \& Aschemann, 2018). Hal ini bisa dilihat pada Gambar 4. Pada Gambar 5, bisa dilihat bahwa Universitas Andalas berkolaborasi dengan Universitas Kitakyushu, Universitas Brawijaya berkolaborasi dengan Universitas Gadjah Mada dan Universitas Miyazaki, sementara itu ITB berkolaborasi dengan Tokyo University of Science.
Sementara itu, kolaborasi antar negara juga divisualisasikan dengan VOSviewer pada Gambar 6. Diketahui total ada 5 negara yang saling berkolaborasi dalam penulisan artikel bank sampah. Dari analisis VOSviewer, ada 3 cluster hubungan negara. Peneliti dari Austria bekerjasama dengan peneliti dari Jerman, dan menulis 1 artikel sekitar tahun 2018. Peneliti dari negara Indonesia bekerjasama peneliti asal Jepang. Dari kerjasama tersebut, diketahui peneliti dari Indonesia menulis 29 artikel, sementara peneliti dari Jepang menulis 8 artikel. Sementara itu, peneliti dari Thailand tidak melakukan kolaborasi dengan negara lainnya, menghasilkan 4 artikel sekitar tahun 2015. 

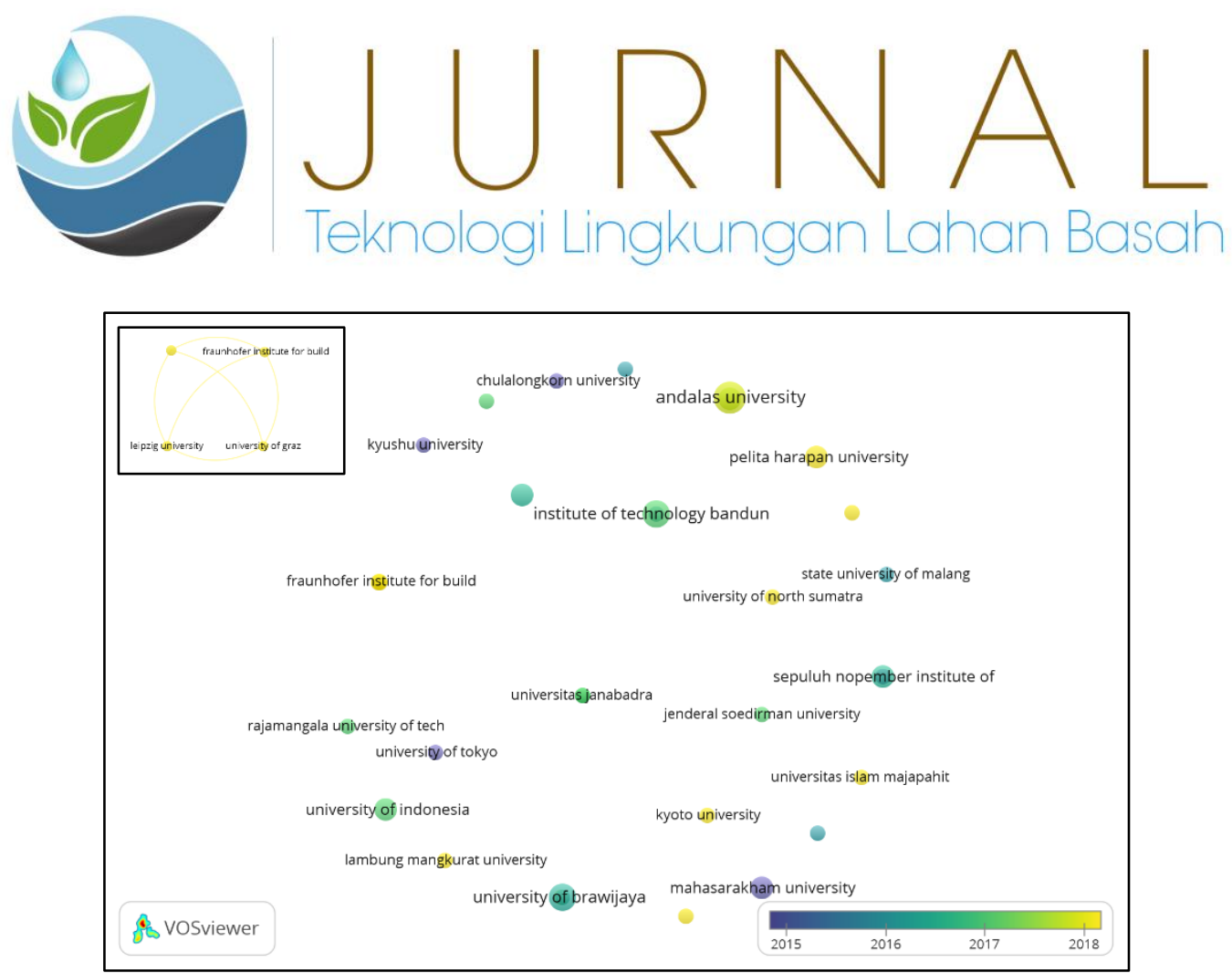

Gambar 4. Visualisasi dari VOSviewer yang memperlihatkan hubungan antar institusi.

Gambar insert memperlihatkan hubungan terbesar yang terdiri dari 4 institusi.

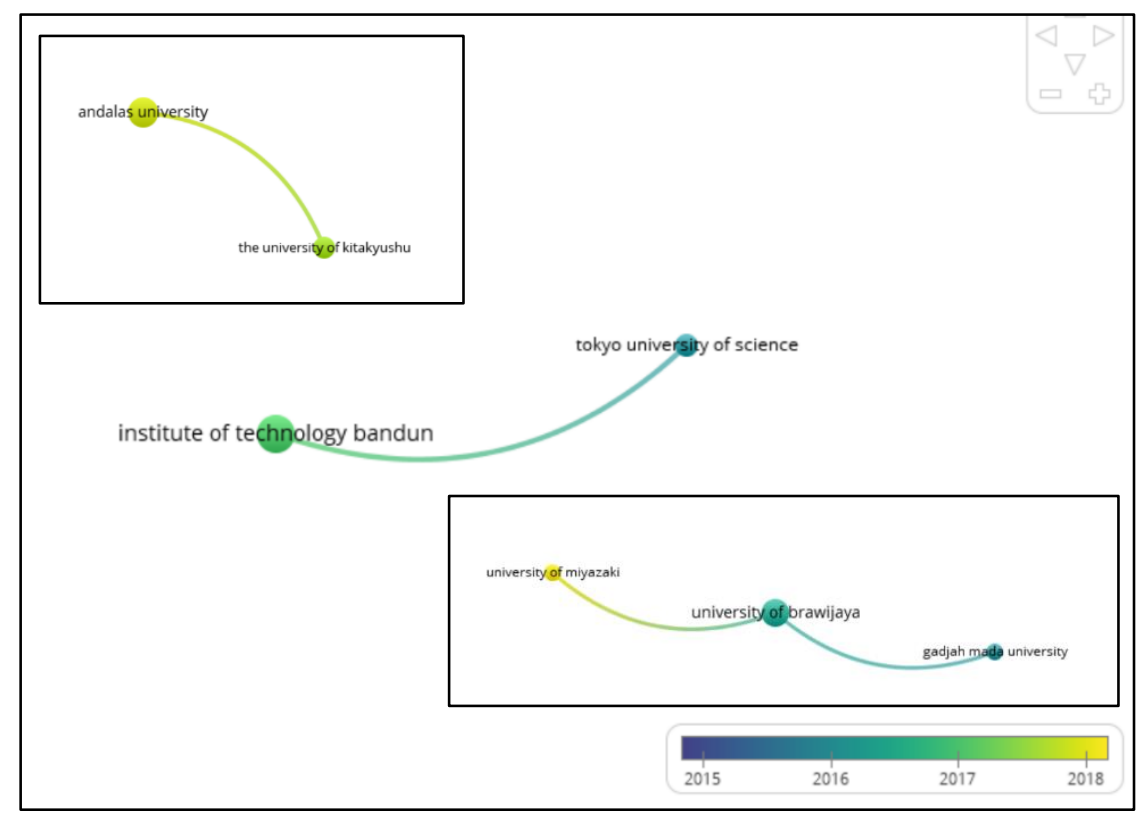

Gambar 5. Visualisasi dengan VOSviewer yang memperlihatkan hubungan antara penulis dari Universitas Andalas, ITB, dan Universitas Brawijaya. 

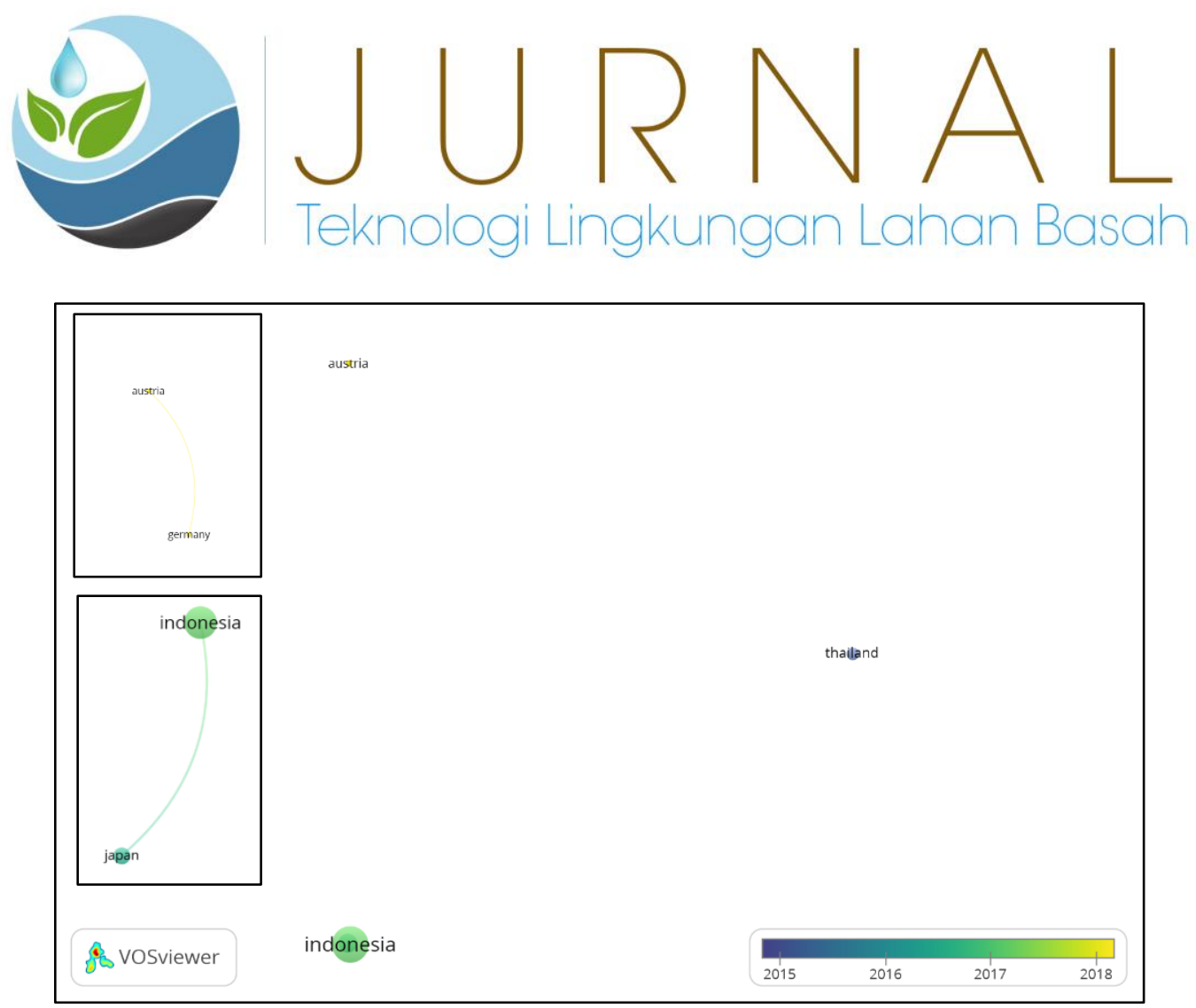

Gambar 6. Visualisasi dengan VOSviewer yang menunjukkan hubungan kolaborasi negara asal penulis. Gambar insert memperlihatkan hubungan penulis asal Austria dan penulis asal Indonesia.

\section{Topik penelitian}

Berdasarkan judul artikel yang telah terbit, juga dapat diketahui topik yang paling banyak ditulis. VOSviewer juga bisa memetakan berdasarkan data tulisan (text). Penelitian ini menggunakan data bibliografik Dimensions dari tahun 2008 hingga 2018. Data tulisan yang diekstrak berasal dari judul artikel, dan diketahui ada 316 topik. Dari nilai tersebut, akan dipilih sekitar $60 \%$ yang relevan, yakni sejumlah 190 topik. Kemudian dengan VOSviewer, akan dipetakan topik yang paling banyak ditulis dan korelasinya dengan topik lainnya. Diketahui ada 49 clusters (kelompok), seperti terlihat pada gambar 7. Detail dari topik artikel bisa dilihat pada Gambar 8.

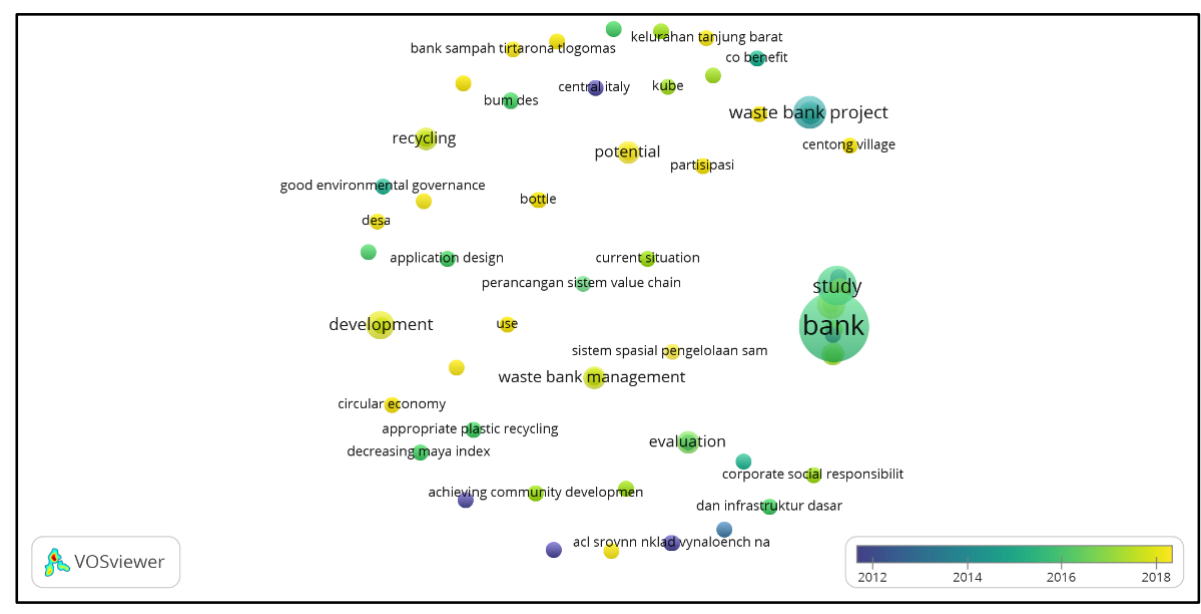

Gambar 7. Visualisasi dengan VOSviewer mengenai topik artikel 

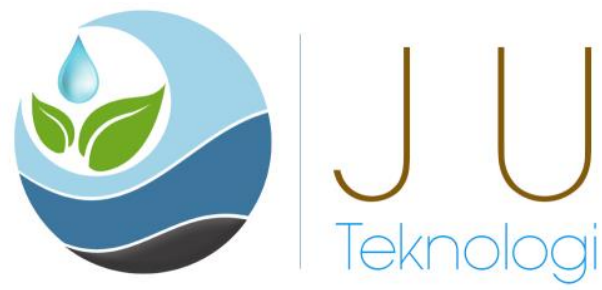

Dari Gambar 7 dapat dilihat bahwa topik yang paling popular dalam penulisan artikel bank sampah adalah "waste bank project" (2014), "bank" dan "study" (2015), “development" (2017). Sementara itu, cluster (kelompok) paling besar terdiri dari 35 bagian, yang terbagi menjadi 7 kelompok, yakni kelompok abandoned mines, audit, study, bank, family, improvement, serta factor. Pada gambar 8 menunjukkan bahwa
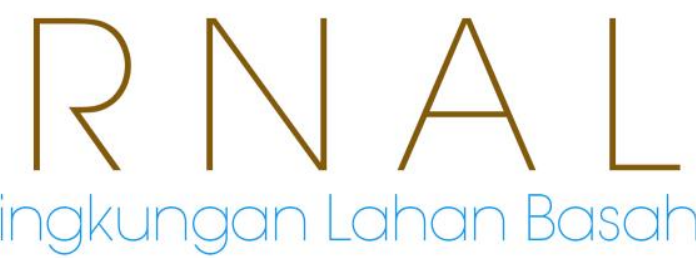

penelitian mengenai Bank terkait dengan tambang yang terbengkalai karena "waste bank" juga digunakan untuk memberi penamaan pada bank limbah (tempat penyimpanan limbah) pertambangan. Terlihat juga bahwa bank sampah masih dalam tahap peningkatan (kajian, faktor, kemajuan) dan umumnya perilaku pengelolaan sampah di bank sampah dilakukan oleh keluarga (family).

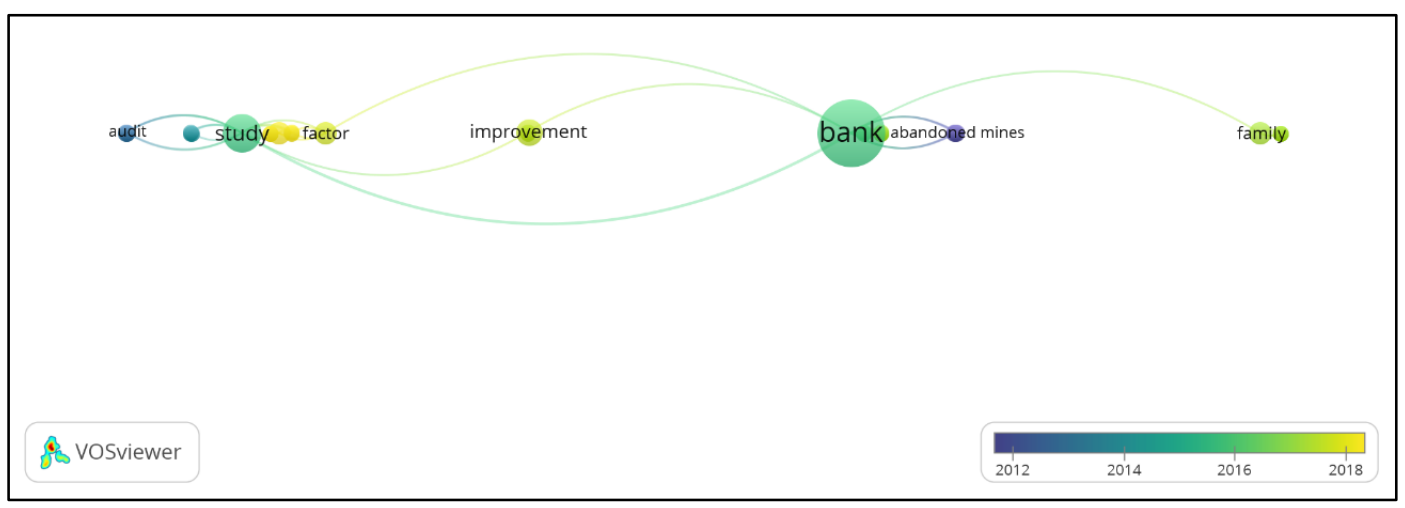

Gambar 8. Visualisasi dengan VOSviewer terhadap cluster terbesar mengenai topik penelitian Bank Sampah

Dari VOSviewer, dapat diketahui juga bahwa bank sampah biasa dibuat pada tingkat rukun warga (RW) dan berkaitan dengan manajemen sampah yang berkelanjutan. Penelitian bank sampah juga dilakukan di Kabupaten Banyumas dalam bentuk eksplorasi studi kasus. Pada kelompok "improvement", penelitian bank sampah terkait pada efektivitas bank sampah pedesaan, kesediaan rumah tangga dalam mengelola sampah, serta adanya penerimaan pemisahan sampah. Hal yang menarik lainnya adalah adanya keterkaitan bank sampah pada kelompok keluarga (family), karena menunjukkan adanya pengembangan karakter pada anak usia sekolah dasar dan kepedulian lingkungan. Sementara itu, pada bagian faktor-faktor yang menentukan keberhasilan bank sampah, terlihat adanya penelitian pada partisipasi rumah tangga terhadap bank sampah Malang, manajemen sampah, dan serta ada penelitian mengenai peninjauan kembali (review) permasalahan pada aktivitas bank sampah pada tahun 2018. Hal ini bertujuan untuk mengevaluasi kinerja bank sampah. 

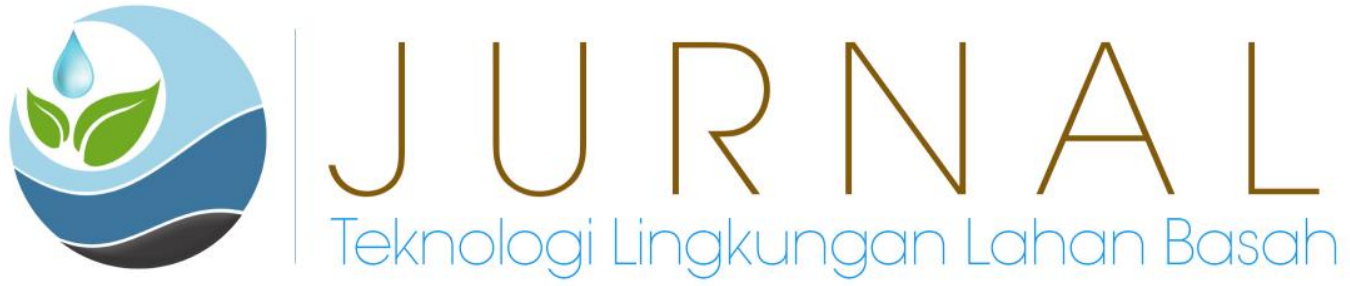

Tabel 3. Artikel yang paling banyak dikutip

\begin{tabular}{|c|l|c|}
\hline No. & \multicolumn{1}{|c|}{ Judul Artikel } & $\begin{array}{c}\text { Jumlah } \\
\text { dikutip }\end{array}$ \\
\hline 1 & $\begin{array}{l}\text { Community participation in household solid waste reduction in } \\
\text { Surabaya, Indonesia (Dhokhikah, Trihadiningrum, \& Sunaryo, 2015) }\end{array}$ & 33 \\
\hline 2 & $\begin{array}{l}\text { Waste Bank as Community-based Environmental Governance: A } \\
\text { Lesson Learned from Surabaya (Wijayanti \& Suryani, 2015) }\end{array}$ & 17 \\
\hline 3 & $\begin{array}{l}\text { Contextual Factors Influencing Household Recycling Behaviours: A } \\
\text { Case of Waste Bank Project in Mahasarakham Municipality } \\
\text { (Singhirunnusorn, Donlakorn, \& Kaewhanin, 2012) }\end{array}$ & 16 \\
\hline 4 & $\begin{array}{l}\text { Co-Benefits of Household Waste Recycling for Local Community's } \\
\text { Sustainable Waste Management in Thailand (Challcharoenwattana \& } \\
\text { Pharino, 2015) }\end{array}$ & 12 \\
\hline 5 & $\begin{array}{l}\text { Community-based solid waste bank program for municipal solid } \\
\text { waste management improvement in Indonesia: a case study of } \\
\text { Padang city (Raharjo, Matsumoto, Ihsan, Rachman, \& Gustin, 2017) }\end{array}$ & 8 \\
\hline 6 & $\begin{array}{l}\text { Household Recycling Behaviours and Attitudes toward Waste Bank } \\
\text { Project: Mahasarakham Municipality (Singhirunnusorn, Donlakorn, } \\
\text { \& Kaewhanin, 2017) }\end{array}$ & 5 \\
\hline 7 & $\begin{array}{l}\text { Community-based Solid Waste Bank Model for Sustainable } \\
\text { Education (Indrianti, 2016) }\end{array}$ & 2 \\
\hline 8 & $\begin{array}{l}\text { Waste Management Scenario through Community Based Waste } \\
\text { Bank: A Case Study of Kepanjen District, Malang Regency, } \\
\text { Indonesia (Purba, Meidiana, \& Adrianto, 2014) }\end{array}$ \\
\hline 9 & $\begin{array}{l}\text { Development of an Ex-Ante Sustainability Assessment Methodology } \\
\text { for Municipal Solid Waste Management Innovations (Wang et al., } \\
\text { 2018) }\end{array}$ & $\begin{array}{l}\text { Integration of formal and informal sector (waste bank) in waste } \\
\text { management system in Yogyakarta, Indonesia (Purnama Putra, } \\
\text { Damanhuri, \& Sembiring, 2018) }\end{array}$ \\
\hline
\end{tabular}

Hal tersebut juga dapat dilihat pada tabel 3 yang mencantumkan sepuluh artikel yang paling banyak dikutip. Kutipan terbanyak terdapat pada artikel-artikel penelitian mengenai adanya pengurangan sampah rumah tangga melalui partisipasi masyarakat, juga mengenai bank sampah yang dijadikan sebagai metode tata kelola lingkungan berbasis masyarakat. Penelitian lainnya mengenai bank sampah adalah faktor- faktor yang mempengaruhi perilaku daur ulang sampah rumah tangga melalui bank sampah serta pemanfaatannya. Dari penelitian juga dapat diketahui adanya skenario pengelolaan sampah melalui bank sampah berbasis masyarakat. Adapun lokasi yang dijadikan penelitian adalah bank sampah yang ada di Surabaya, Yogyakarta, Padang, Malang, dan Mahasarakham di Thailand. 

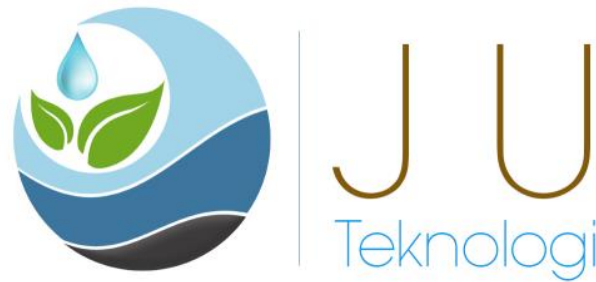
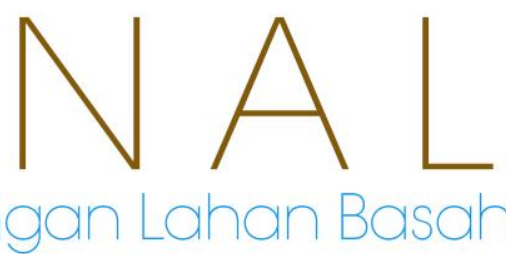

\section{KESIMPULAN}

Penelitian bank sampah untuk pengelolaan persampahan diperkirakan dimulai pada tahun 2008 di Thailand. Kemudian semakin meningkat sejak 2015. Namun di Indonesia, penelitian bank sampah dimulai sekitar tahun 2014 . Topik penelitian yang diangkat antara lain mengenai partisipasi rumah tangga dalam mengelola sampah, adanya metode pengurangan timbulan sampah

\section{DAFTAR PUSTAKA}

Challcharoenwattana, A., \& Pharino, C. (2015). Co-benefits of household waste recycling for local community's sustainable waste management in Thailand. Sustainability (Switzerland), 7(6), 7417-7437. https://doi.org/10.3390/su7067417

Damanhuri, E., \& Padmi, T. (2016). Pengelolaan Sampah Terpadu (Pertama). Bandung: Penerbit ITB.

Dhokhikah, Y., Trihadiningrum, Y., \& Sunaryo, S. (2015). Community participation in household solid waste reduction in Surabaya, Indonesia. Resources, Conservation and Recycling, 102, 153-162.

https://doi.org/10.1016/j.resconrec. 2015.06.013

Indrianti, N. (2016). Community-based Solid Waste Bank Model for Sustainable Education. Procedia Social and Behavioral Sciences, 224(August 2015), 158-166. https://doi.org/10.1016/j.sbspro.20 16.05.431

Lestari, S. (2012). Bank Sampah, ubah sampah jadi uang. Retrieved from https://www.bbc.com/indonesia/ma jalah/2012/07/120710_trashbank

Menteri Negara Lingkungan Hidup rumah tangga melalui bank sampah, perubahan perilaku dalam kepedulian lingkungan, serta adanya penelitian mengenai faktor-faktor yang mempengaruhinya. Kombinasi tinjauan pustaka sistematis (SLR) yang berbasis data lainnya perlu dilakukan untuk melengkapi analisis bibliometrik pada penelitian bank sampah untuk pengelolaan persampahan.

Republik Indonesia. (2012).

Peraturan Menteri Negara Lingkungan Hidup Republik Indonesia Nomor 13 Tahun 2012 Tentang Pedoman Pelaksanaan Reduce, Reuse, Dan Recycle Melalui Bank Sampah.

Okoli, C., \& Schabram, K. (2010). (Okoli, Schabram 2010 Sprouts) systematic literature reviews in IS research. Working Papers on Information Systems, 10(26), 1026. Retrieved from http://sprouts.aisnet.org/10-26

Pemerintah Indonesia. (2008). UndangUndang Republik Indonesia Nomor 18 Tahun 2008 tentang Pengelolaan Sampah. Lembar Negara RI Tahun 2008 Nomor 4851. (1).

PRESIDEN REPUBLIK INDONESIA. (2012). PERATURAN PEMERINTAH REPUBLIK INDONESIA NOMOR 81 TAHUN 2012 TENTANG PENGELOLAAN SAMPAH RUMAH TANGGA DAN SAMPAH SEJENIS SAMPAH RUMAH TANGGA. 3(September), $1-47$.

Purba, H. D., Meidiana, C., \& Adrianto, D. W. (2014). Waste Management Scenario through Community 

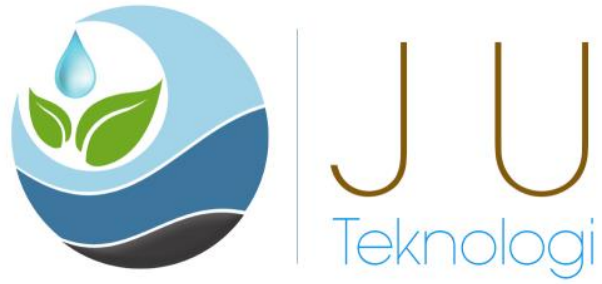

Based Waste Bank: A Case Study of Kepanjen District, Malang Regency, Indonesia. International Journal of Environmental Science and Development, 5(2), 212-216. https://doi.org/10.7763/ijesd.2014. v5.480

Purnama Putra, H., Damanhuri, E., \& Sembiring, E. (2018). Integration of formal and informal sector (waste bank) in waste management system in Yogyakarta, Indonesia. MATEC Web of Conferences, 154, 1-5. https://doi.org/10.1051/matecconf/ 201815402007

Raharjo, S., Matsumoto, T., Ihsan, T., Rachman, I., \& Gustin, L. (2017). Community-based solid waste bank program for municipal solid waste management improvement in Indonesia: a case study of Padang city. Journal of Material Cycles and Waste Management, 19(1), 201212.

https://doi.org/10.1007/s10163-

015-0401-z

Singhirunnusorn, W., Donlakorn, K., \& Kaewhanin, W. (2012). Contextual Factors Influencing Household Recycling Behaviours: A Case of Waste Bank Project in Mahasarakham Municipality. Procedia - Social and Behavioral Sciences, 36(June 2011), 688-697. https://doi.org/10.1016/j.sbspro.20 12.03.075

Singhirunnusorn, W., Donlakorn, K., \& Kaewhanin, W. (2017). Household
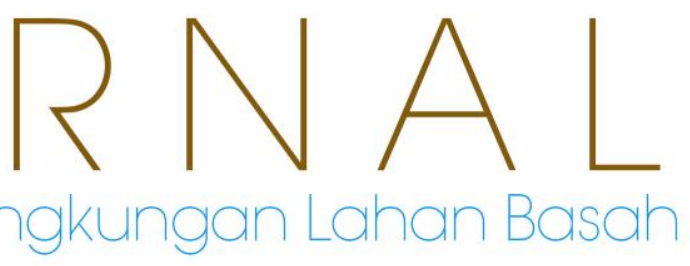

Recycling Behaviours and Attitudes toward Waste Bank Project: Mahasarakham Municipality. Journal of ASIAN Behavioural Studies, 2(5), 17. https://doi.org/10.21834/jabs.v2i5. 215

Ulfa, Y., Irawan, D. E., \& Kombaitan, B. (2019). Analisis Bibliometrik dari Penelitian Geologi untuk Tata Guna Lahan Perkotaan: 19502019.

van Eck, N. J., \& Waltman, L. (2017). Citation-based clustering of publications using CitNetExplorer and VOSviewer. Scientometrics, 111(2), 1053-1070. https://doi.org/10.1007/s11192017-2300-7

Wang, J., Maier, S. D., Horn, R., Holländer, R., \& Aschemann, R. (2018). Development of an ex-ante sustainability assessment methodology for municipal solid waste management innovations. Sustainability (Switzerland), 10(9). https://doi.org/10.3390/su1009320 8

Wijayanti, D. R., \& Suryani, S. (2015). Waste Bank as Community-based Environmental Governance: A Lesson Learned from Surabaya. Procedia - Social and Behavioral Sciences, 184(August 2014), 171179.

https://doi.org/10.1016/j.sbspro.20 15.05.077 